\title{
The Arab Spring: A Revolution for Egyptian Emigration?
}

Le "printemps arabe": une révolution pour l'émigration égyptienne?

La « primavera árabe » : ¿una revolución para la emigración egipcia?

\section{Delphine Pagès-El Karoui}

\section{(2) OpenEdition Journals}

\author{
Electronic version \\ URL: https://journals.openedition.org/remi/8481 \\ DOI: 10.4000/remi.8481 \\ ISSN: $1777-5418$ \\ This article is a translation of: \\ Le « printemps arabe » : une révolution pour l'émigration égyptienne ? - URL : https:// \\ journals.openedition.org/remi/7417 [fr]
}

\section{Other translation(s): \\ Roma and Gypsies in the Mediterranean: Circulating Categories, Maintaining Boundaries - URL : https://journals.openedition.org/remi/8478 [en] \\ "The cinema needs the individual, and migrants need the cinema to re-emerge as an individual." Interview with Andrea Segre - URL : https://journals.openedition.org/remi/8595 [en] Mapping the Migratory Movements - URL : https://journals.openedition.org/remi/8803 [en] The measure of migratory flows between France and other countries; what if we also spoke of emigration? - URL : https://journals.openedition.org/remi/12090 [en] Immigrant Youth in Canadian Postsecondary Education: Pathway Morphologies in the Province of Quebec - URL : https://journals.openedition.org/remi/12100 [en]}

Publisher

Université de Poitiers

\section{Printed version}

Date of publication: 1 December 2015

ISBN: 979-10-90426-26-9

ISSN: 0765-0752

Electronic reference

Delphine Pagès-El Karoui, "The Arab Spring: A Revolution for Egyptian Emigration?", Revue européenne des migrations internationales [Online], vol. 31 - n³ et 4 | 2015, Online since 01 December 2017, connection on 14 April 2022. URL: http://journals.openedition.org/remi/8481 ; DOI: https://doi.org/ 10.4000/remi.8481

This text was automatically generated on 14 April 2022.

(c) Université de Poitiers 


\title{
The Arab Spring: A Revolution for Egyptian Emigration?
}

\author{
Le "printemps arabe ": une révolution pour l'émigration égyptienne? \\ La « primavera árabe » ¿ ¿una revolución para la emigración egipcia?
}

Delphine Pagès-El Karoui

"Me, I got out of there, I left Egypt partly for the same
reasons that caused the revolution [...] It was for social
justice, I felt like we weren't free in Egypt, that there
are things we can't say, can't do." Hussain, Paris, 15
Feb 2013 (cited in Ricci, 2013: 86).

1 In Egypt, emigration and revolution have structurally similar causes. The economic (unemployment, underemployment, low wages, etc), political (authoritarianism, corruption, clientelism, etc) and social (socio-spatial inequalities, patriarchy, high marriage costs, etc) dysfunctions that are among the main reasons for emigrating are, at the same time, the elements that sparked the 25 January 2011 revolution (Pagès-El Karoui and Vignal, 2011). Large-scale emigration has been encouraged by Egyptian public authorities since the 1970s, particularly for those with higher education. It has been a way of escaping the country's dysfunctions, but also a means for exporting latent contestation and reinforcing structures of authoritarian domination, by preventing the renewal of elites (Bel-Air, 2014). It has also contributed to the transformations of Egyptian society (individualisation, the growth of consumer society, openness to the rest of the world, etc) that made a popular uprising against the authoritarian regime and the fall of president Mubarak possible (Pagès-El Karoui, 2012a). Has Egyptian emigration augmented or otherwise been altered as a result of the unsettling of public order in Egypt and the region? ${ }^{1}$

22011 is undeniably a key date in the history of the Arab world. Can the same be said of it with respect to Egyptian migrations? ${ }^{2}$ Did the year 2011 bring to a close the migratory cycle begun in 1990 with the Gulf war, which caused numerous Egyptians to return from Iraq and the oil-rich countries of the Arabian Peninsula? This article examines how Egyptian emigration has been affected by the political, economic and 
geopolitical turbulences connected to the Arab revolutions. It focuses on two angles. First, have the political and geopolitical changes initiated since 2011 created any major shifts either in terms of the scale or destination countries of emigration flows from Egypt? The revolutionary period considerably modified the migratory imaginary prevalent among the Egyptians who choose to leave Egypt or remain living abroad, as well as in destination countries. The re-founding of the national narrative-or national imaginary, following Benedict Anderson's (2006) work-crystallized around Tahrir Square. During the 18 days that preceded Mubarak's fall, Egyptians imagined the possibility of a new Egypt, rid of its divisions and dysfunctions, more democratic and egalitarian, in which they might build a future without having to expatriate themselves.

3 The Egyptian case well illustrates the extreme volatility of the revolutionary situation, which is accompanied by brutal changes and reversals. Taking into account different temporalities is therefore necessary to gain a good grasp of the processes. During the transition period managed by the military, once the common enemy (Mubarak) disappeared, the intense feeling of national unity experienced during the 18 days (25 January - 11 February 2011) rather quickly collapsed. The national narrative subsequently took on a more Islamist and less democratic hue during the presidency of the Muslim Brotherhood candidate, Mohamed Morsi (June 2012-July 2013). Finally, the army's return to power, following huge public discontent, confirmed by the subsequent election of General Sisi as president in June 2014, has adjourned the political transition for a time. The shockwaves of these successive reversals propagated themselves through the Egyptian diasporas.

This leads to the article's second question: how did Egyptians living abroad experience these historic events? The argument made here is that during an initial period, the revolutionary process intensified emigrants' transnational practices and perhaps briefly initiated a process of 'diasporization,' that is, the construction of a feeling of belonging to an Egyptian diaspora, a national collective outside the country's territory and going beyond its multiple divisions. This feeling disappeared quickly, in a manner that echoes the divisions emerging inside Egypt. Each of these four periods generated different impacts on the flows and transnational connections of Egyptian migrants.

\section{What were the Impacts of the Arab Revolutions on Migratory Flows of Egyptians?}

This section examines how the postrevolutionary context affected return by Egyptians living abroad, while at the same time causing new departures. Migratory policy was transformed more in countries that employ Egyptian workers than in Egypt itself.

\section{Voluntary, Forced, and Deferred Returns}

Quantifying the effects of the Arab revolutions on Egyptian migratory flows is challenging when already we have a hard time even estimating the number of Egyptians living abroad: estimates vary between 2 and 8 million people (Abdelfattah, 2011; Fargues and Fandrich, 2012; Zohry, 2013). It is even more difficult to estimate how many may have returned since 2011, since returns are by definition harder to quantify. 


\section{Voluntary (and often Temporary) Returns of Qualified Migrants}

7 Buoyed by the great hope of rapid change, many migrants, especially qualified ones, left their lives abroad behind in order to participate in the revolution, then in the country's reconstruction (Premazzi, Ambrosetti, Cela and Fokkema, 2013). Wael Ghunim (2012), the administrator of the We Are All Khaled Said Facebook group, ${ }^{3}$ left his job in Dubai as a regional marketing director for Google in order to participate in the $25^{\text {th }}$ of January protest. Canadian-Egyptian writer and university professor May Telmissany has a similar story, recounting how 'after the revolution, I wanted to go back home and participate in the struggle against the dictatorship. ${ }^{4}$ Or Mohamed, for example, who has been living in France since 2000. Having initially contributed to organizing the mobilization in France, he decided on 9 February to return to Egypt so that he could go to Tahrir square, but in the end he remained only 1 month. ${ }^{5}$ These sorts of cases often involve dual nationals residing in the West. ${ }^{6}$ Unlike in Tunisia, where many French-Tunisians participated in postrevolutionary governments, these dual citizens were not offered similar positions in Egypt. However, like in Tunisia, they were often seen as foreigners: May Telmissany recounts how during the protests people spoke to her in English and were very surprised when she replied to them in Arabic that she is Egyptian.

Emigrant return is at the heart of the 2014 Ramadan television series Ambrâturiyat Mîn (Whose Empire?). ${ }^{7}$ The series depicts the return of Amira, a British-Egyptian who, full of hope and ambitions to contribute to the emergence of a new Egypt, convinces her family to leave their beautiful villa in London in order to return to Cairo and take part in the revolution. The series plays off the interweaving of the heroine's personal story -a sequence of disillusionments and frustrations-with postrevolutionary events. From the moment she boards the plane, Amira realizes that her vision of the Egypt she left long ago no longer corresponds with the Egypt of 2011. Her good intentions and quest for an authentic Egypt that she lost are repeatedly thwarted. The first episode comes to an end with Amira arriving in Egypt handcuffed at the back of the plane, after she became exasperated at the incivilities she had to suffer during the trip. This scene foreshadows the final episode in which Amira and her family are arrested for foreign espionage, on the basis of accusations fabricated by the secret service and media. It is thus indeed the loyalty of bi-nationals that the political powers doubt.

Even if most had the intention to return to live in Egypt permanently, their optimism was short-lived and a significant number went back to their adopted countries.

\section{Forced Returns from Libya}

Several hundred thousand Egyptians returned from Saudi Arabia in 2013, in the context of expulsions of irregular migrants (see below) and an equally large number were forced to flee Libya. Libya, which had opened its doors at the beginning of the $1990 \mathrm{~s},{ }^{8}$ at a time when departures to Iraq were abating because of the Gulf war (Fargues, 2000), had a large number of Egyptian workers. These were principally migrants with low qualifications from poor regions such as Upper Egypt, working in sectors like construction. In 2011, the country slid rapidly toward civil war. Following a Western intervention in March, Gadhafi fell in October. This sparked the largest migratory crisis in the region since that of the 1990 Gulf war and prior to the Syrian tragedy, which would force the exodus of millions of people. Both Libyans and foreign workers arrived 
at the country's borders, fleeing the fighting. Their countries of origin as well as international organizations such as the IOM (International Organization for Migration) and the HCR (High Commission for Refugees) mobilized to assist in repatriating the refugees (Abdelfattah, 2011).

There were several distinct waves of Egyptians returnees: in 2011, several hundred thousand returned to Egypt, either directly, or via Tunisia if they lived in western Libya (Zohry, 2013). ${ }^{9}$ In the summer of 2014, after the violent clashes in Tripoli, 15,000 Egyptians left the country. The third wave occurred in February 2015, when the official number of Egyptian migrants was estimated to be $200-250,000$ people. ${ }^{10}$ More than 50,000 Egyptians returned after the decapitation of 21 Coptic (Christian) Egyptians by IS (Islamic State) whose killing was immediately publicized on social media. Egypt responded with retaliatory air strikes against IS, with help from the Emirates. During this period, other Egyptians, many of whom were Copts, were kidnapped or killed, generally by Islamist militias. Egyptians migrants were thus hostages of regional geopolitics and Copts constituted a doubly symbolic target, both as Christians in a context of sectarian violence, and as Egyptians, in retaliation against their country's policies, being doubly accused by their aggressors of supporting the loyalists in the East of Libya and having ousted the Muslim Brotherhood in Egypt in July 2013.

Egyptian authorities feared the impact of these massive returns on an already disastrous labour market. The returnees and their families found themselves in such difficult conditions that Egypt requested the World Food Programme put in place assistance programmes in certain governorates in Upper Egypt, which offered food in exchange for recipients taking professional training programmes. ${ }^{11}$ The IOM launched information platforms to assist in the reintegration of returnees, in particular by providing them with access to employment offers and health services. ${ }^{12}$ Due to this extreme vulnerability, the poorest migrants fairly quickly returned to Libya, despite the Egyptian government's warnings that its citizens should not travel there. Some used illegal channels, and several Egyptians were found dead in the desert, abandoned by smugglers. In early July 2015, dozens of Egyptians were arrested in proximity to the Salloum border crossing or the Siwa Oasis while trying to enter Libya illegally. ${ }^{13}$ Despite the collapse of the Libyan state, the fight against illegal immigration continues: in 2013, 2,000 Egyptians were prevented from returning to Libya after the Eid holidays because they lacked valid residence visas ${ }^{14}$ and 360 were expelled directly from the Misrata airport for holding falsified residency permits.

\section{Deferred Returns}

The current situation in Egypt appears so catastrophic that if they have the possibility of doing so, many Egyptians abroad are putting off their return. Among migrants interviewed in the Emirates in 2014 and 2015, the vast majority did not wish to return at that time. Some even wished to move onward to a Western country, often Canada, in order to obtain another nationality. This strategy, which existed prior the revolution but has been bolstered since, allows for minimizing the risks of the revolution. Having a Western passport offers the educated middle and upper classes the security of much more flexible international movement than holders of an Egyptian passport alone. Once they have acquired this passport, some do not hesitate to return to Egypt or the Gulf with this ace up their sleeve that will allow them to leave again easily. In an American school in Maadi, a upscale neighbourhood to the south of Cairo, nearly half of the 
registered pupils are dual citizens with American passports. ${ }^{15}$ Canada recently adopted a new citizenship law that threatens to thwart these projects: the required period of residency in order to obtain citizenship has been lengthened and a declaration of intent to reside in the country is now obligatory, in order to avoid what the government refers to as 'citizenship of convenience.'

\section{Departures: Emigration Continues}

Several polls (IOM, 2011; Zohry, 2013) downplay the impact of the revolution on the desire to emigrate: those who, after 2011 , wished to leave the country generally already intended to do so prior to that date. However new reasons emerged, such as insecurity and instability. According to another poll, repeated on several occasions in August 2011 and December 2014, the percentage of the population wishing to emigrate varied between 11 and $17 \%{ }^{16}$ Departures therefore continue, unchecked by the return to authoritarianism under General Sisi and his endeavours to restart the economy in a lasting way.

\section{Changes and Continuities in Emigrant Profiles}

Young men with low levels of qualifications who are not able to find work leave for other Arab countries or grow the ranks of irregular migrants in Europe. Like in Tunisia, the collapse of the state in the early months of 2011 provided those wished to do so with opportunities to leave illegally. A number of unaccompanied minors took their chances, since they are reputed not to be expelled upon arrival in Europe. Already in $2008,35 \%$ of irregular migrants from Egypt intercepted in Lampedusa ${ }^{17}$ were male unaccompanied minors. ${ }^{18}$ During Morsi's presidency, Copts emigrated massively toward the Coptic diaspora's traditional destinations: the United States, Canada, Australia, and Europe. ${ }^{19}$ Their reasons for departure can be simultaneously economic and political, even if some avoid foregrounding the religious dimension when interviewed. Some entrepreneurs have turned away from Egypt to start businesses in the Gulf: for some, Dubai is a fallback where they establish their families while moving back and forth for business between the Gulf and Egypt. People belonging to the middle and upper classes establish themselves in the Gulf or North America due to fear of the internal political situation and insecurity. After the destitution of president Morsi in July 2013 and the Rabaa Al-Adawiya square massacre, leaders of the Muslim Brotherhood exiled themselves to Qatar, Tunisia, or Turkey. After the army's return to power, a few intellectuals (a minority, since the majority support the army) and artists also left. For example Mohamed Hashem, a revolutionary hostile to the current regime and founder of a large Egyptian publishing house, Meritt, announced on his Facebook page in October 2013 that he was leaving Egypt and that he considered emigration the only possible avenue in the face of the elite's deafening silence.

16 Thus, the profiles of those who have left Egypt after 2011 can vary according to political temporalities, without there being any profound break with the prior period.

\section{Unchanged Destinations and Reduced Opportunities to Migrate}

17 Young Egyptians interviewed in March 2011 preferred five destinations: Saudi Arabia, the United Arab Emirates, the United States, Kuwait and Italy (IOM, 2011). The absence 
of statistical data in the Gulf prevents us from ascertaining how many Egyptians are there and whether they are fewer or more numerous since 2011. However fieldwork suggests increased difficulty in emigrating to the Gulf after 2011. Fearing the spread of contestation, ${ }^{20}$ the Gulf countries, in particular Saudi Arabia and the Emirates, both of which are major destination countries for Egyptians, modified their policies. On the one hand, they reinforced security checks on migratory flows coming from countries experiencing revolutionary contestation-for example by taking care not to allow in Egyptians known to be revolutionaries or Islamists (with the exception of Qatar, which accepted Muslim Brothers) -and on the other, they revived workforce nationalisation policies and created unemployment allowances so as to avoid generating among their citizens the 'prerevolutionary' conditions of a class of rebellious youth graduates without employment.

In the Emirates, just after Mubarak's fall, numerous Egyptians' work permits or existing employment contracts were not renewed. The fear of revolutionary contagion is not the only reason for these measures. It is probable that the Egyptian migrants were pawns in bilateral diplomatic and economic relations between the two countries. This closure was interpreted by some Egyptians as an expression of the Emirates' dissatisfaction with respect to the decision to put Mubarak on trial and the rapprochement with Iran, as well as irritation at the freezing of large Emirati real estate developments in Cairo's new cities, which were accused of involving illegality and corruption for which several Egyptian ministers were imprisoned (Abdelfattah, 2011). Fieldwork conducted in 2014 and 2015 confirmed these persistent difficulties for Egyptians seeking to renew their residence permits or come to work in the Emirates. The Emirates expelled Egyptians belonging to the Muslim Brotherhood and quickly sent home Egyptian migrants who expressed support for Bin Laden after his death in 2011. ${ }^{21}$ However, it is clear that Egyptians continued to establish themselves in Dubai after the revolution. Since 2013 the two countries have had good relations and have conducted joint military operations in Libya. The Emirates also support Egypt financially.

19 In June 2011, Saudi Arabia modified its immigration control policy, prioritising the struggle against illegal immigration: several hundred thousand foreign workers were expelled (Thiollet, 2013; Beaugrand, 2013), and according to the press 300,000 Egyptians voluntarily left the country because they were in irregular situations..$^{22}$ In parallel, Riyadh launched a policy aimed at the 'Saudi-ization' of the workforce. Although these measures do not directly target Egyptians in the way some have claimed (Abdelfattah, 2011), they do nevertheless affect them insofar as Egyptians are one of the largest foreign communities in Saudi Arabia.

2011 does not appear to have resulted in major shifts in other countries and regions of the world (Fargues and Fandrich, 2012), except some that were already underway: in Jordan, where Egyptians represent $82 \%$ of the active foreign male population (Roussel, 2012), the number of work permits decreased by $11 \%$ between 2009 and 2010 (Pagès-El Karoui, 2015), which supports Françoise de Bel-Air's claim (2014) that the Arab revolutions were sparked in a context of reduced migratory opportunities caused by the economic crisis of 2008 and the renewal of workforce nationalisation policies. In 2009 , seeing the level of unemployment increase and fearing a massive return of emigrants, Egyptian authorities feared an imminent migration crisis (Zohry, 2009). In the United States, a decrease is also visible between 2009 and 2011 in the attribution of 
permanent resident status, after which the number again increased, starting in 2012 (Figure 1). For naturalizations, the curve is approximately the same (Figure 2).

In Europe, on the other hand, according to Eurostat, Egyptian emigration has increased since 2007: by $19 \%$ in Germany, $22 \%$ in the UK, $45 \%$ in Spain and $58 \%$ in Italy. The number of residency permits has been increasing constantly since 2008: in 2013, nearly 200,000 Egyptians were official residents in Europe, of which 135,000 in Italy. However in Italy the number of first-time residency permits issued has considerably decreased: 12,855 were issued in 2011 , compared to 20,532 in 2010 . Italy, which is facing very strong migratory pressure, increasing since the Arab revolutions, has perhaps chosen to be stricter toward new arrivals, while at the same time allowing the already established Egyptian community to renew its residency permits.

\section{Figure 1: Number of Egyptians Obtaining Permanent Residency Status in the United States}

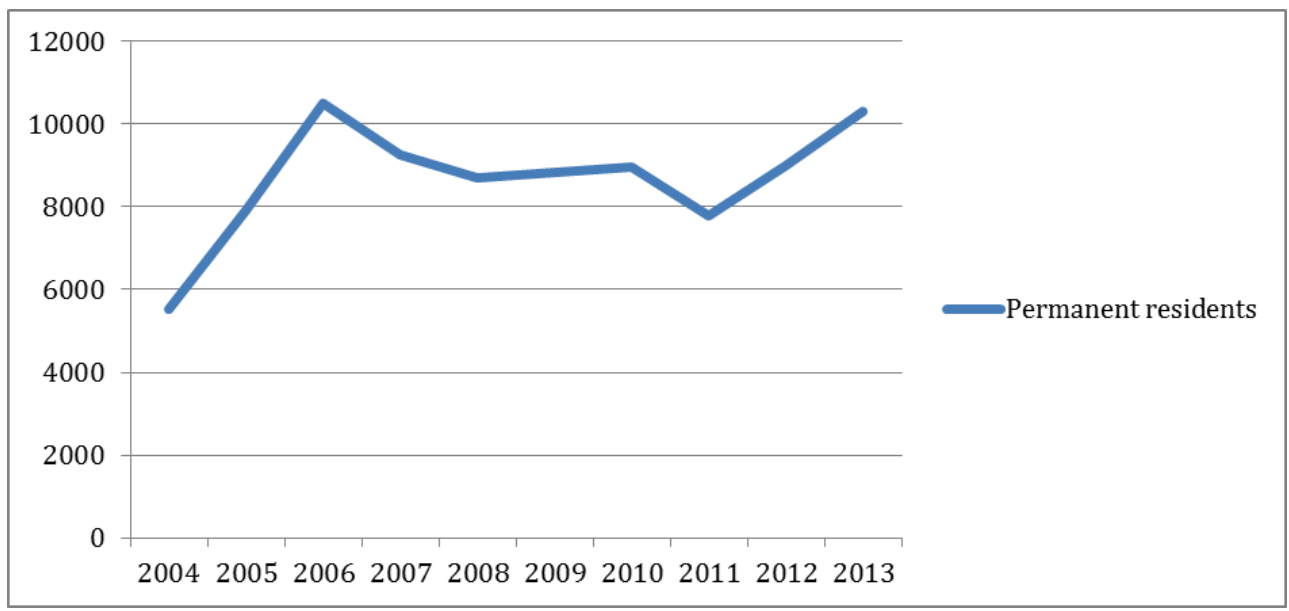

SOURCE: U.S. DEPARTMENT OF HOMELAND SECURITY.

Figure 2: Naturalisations of Egyptians in the United States

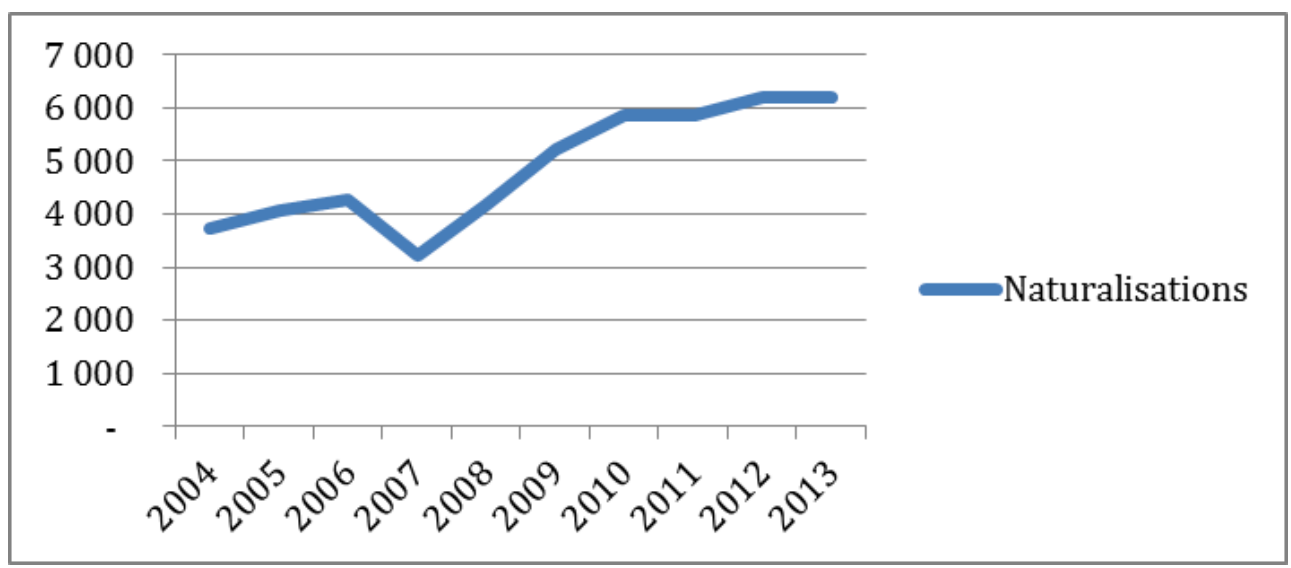

SOURCE: U.S. DEPARTMENT OF HOMELAND SECURITY. 


\section{Revolution as a Determinant of Migratory Trajectories?}

In some cases, the revolution played a determinant role in departure. Thus, Medhat, who ran two tourism and consulting companies in Egypt, left his country just after the revolution, in March 2011:

'After the revolution, I saw that Egypt was descending in chaos [fawda]. I had no income for two months, either in consulting or tourism. I lost my contracts in Egypt and Libya' (Medhat, Dubai, 2015).

He initially left, alone, to England, where his in-laws were well-established. He opened an apartment rental company focusing on tourists from the Gulf, but with the crisis only managed to get by. He then decided to establish himself in Dubai where he had a job offer, and his family joined him there. After working in several companies, at the beginning of 2015 he opened his own business, a branch of an Asian tourism company. He explains that he made this decision when he understood that he would not be able to return to Cairo for several years, having seen the impact of the wars in Libya, Syria and Yemen, and the effects of Daesh.

For Rania, a single engineer in her thirties who lived alone in Dubai between 2012 and 2014, expatriation had nothing to do with the revolution, but was closely linked to her personal history. She left following a breakup, but was not satisfied by the lifestyle in Dubai, which she considered superficial. After a year, she took the decision to come back to Egypt. Interviewed in Cairo in January 2015, she was contemplating returning to Dubai:

'In Cairo, after the revolution, you move around less, you prefer to stay at home. We see each other less. My friends don't feel safe enough to see each other anymore, and social life is less full. [...] I say the same thing to those who want to come back for family. Stay there, you don't see one another that much anyway.' ((Rania, Le Caire, January 2015)

This question of insecurity is often present in the discourse of migrants, for whom it is sometimes a reason for leaving. ${ }^{23}$

\section{The Consequences of the Arab Revolutions on Migratory Policies}

Except for the right to vote accorded to Egyptians abroad in 2011, Egyptian policies related to emigration were not significantly changed by the revolution. ${ }^{24}$ The issue has not been a priority for the ruling powers. Under president Morsi, the Muslim Brotherhood's objective was to favour circulatory migrations, generally in the direction of Arab countries, and there was concern about competition from Asian workers in the Gulf (Hafez and Ghaly, 2012). The revolutions did however have an impact on migratory policies in the Gulf countries, as we have just seen, as well as those in Europe. While Libya has become the principal point of departure for boats trying to cross the Mediterranean, many of which have tragically sunk since 2015, boats also leave from the Egyptian coast, in places like Alexandria, Rosetta, or Damietta. The European Union began discussions with Egypt and Tunisia, in the hope of involving them more in surveillance of the Libyan coast and rescue of migrants. Europe's increasing efforts to externalize its migratory policies toward the southern margins are one of the major impacts of the Arab revolutions on the Mediterranean migratory system. But this is not really a novelty.

While it is complicated to establish a balance sheet with respect to the impact of the Arab revolutions on flows of Egyptians, since departures and returns are both difficult 
to quantify and work in both directions, offsetting one another, the impact on expatriate communities is more legible, though its analysis still requires attention to different temporalities and highly changing political contexts.

\section{The Repercussions of the Revolution on Egyptians Abroad}

Initially, the revolutionary process corresponded to an intensification of transnational practices for many Egyptians living abroad: renewed interest and reinforced ties with Egypt (increased remittances, real or virtual contact on social media, political mobilization, etc), and the emergence of new transnational practices, such as overseas voting or protests in countries of residence. Often discreet and relatively unknown in their countries of residence, Egyptians acquired a new visibility, insofar as they began to group together and mobilize. Can we go further and see these events as contributing to the construction of an emergent diaspora? This is very unclear since although the aftermath of the 25 January revolution has been interpreted as a moment when Egyptians abroad, who were very little organized, began to meet, overcoming their differences, the fall of president Morsi in July 2013 initiated a process of disintegration among this group.

\section{Mobilisations Abroad}

\section{Renewed Pride in being Egyptian}

Among Egyptians abroad, the 25 January revolution, referred to as the 'revolution of dignity,' renewed a feeling of deep attachment to the home country, combined with new feelings of pride and shared destiny. After Mubarak's fall, emigrants seized on the imaginary of a new Egypt forged during the 18 days on Tahrir Square, which had become a revolutionary icon. This utopian moment during which Egyptian society dreamed of itself as united and capable of overcoming all of its divisions allowed for a reinvention of the national narrative (Pagès-El Karoui, 2014) and strengthened ties between emigrants and their country of origin, including among the second generation (Premazzi, Ambrosetti, Ceka, Fokkema, 2013; Soudy, 2013). Thus, Ahmed, an EgyptianAmerican living in Washington stated:

Because it was something to be proud of, Egyptians were doing something historic [...]. How could you not feel proud? If ordinary non-Arab, non-Egyptian people were looking at Egypt with a huge sense of pride and inspiration, how could I as an Egyptian not feel that pride? And in my mind, I had always felt that Egyptian nationalism, modern nationalism, is so shallow, because it is mostly chauvinism, it is mostly about 7000 years of history, and the Pharaohs, etc. [...] Suddenly, there was something to be proud of. (Soudy, 2013: 139)

31 This reactivation of national pride may have driven returns, as some emigrants fervently wished to participate in the democratic transition. For those who did not return, the Egyptian flag became a marker of identity: displayed in cars and apartments, it attested to this patriotic pride. 


\section{Transnational Political Engagement} that they spent large amounts of time in front of the television and on social media. Thanks to internet, emigrants could follow the unfolding events and communicate with protesters. An analysis of more than 3 million tweets containing six keywords (hash tags) connected to the Arab revolts (such as \#egypt or \#sidibouzid, for example) showed that a very large number of messages were posted and shared by expatriates (Zhuo, Wellmann and $\mathrm{Yu}, 2011)$. In general, many concerned expatriates participated in street protests organized in Western countries and became very involved in processes of transnational politicization (Müller-Funk, 2014). ${ }^{25}$ However, Simona Ricci (2013) shows that many only followed the events on Facebook. Thus, an Egyptian activist living in Paris lamented that the majority of his fellow Egyptian citizens belong to the 'couch potato party,' a very evocative expression.

Egyptians abroad remember the 18 days as a moment of intensity that sometimes upended their social lives: new friendships were formed, couples got together or broke up, people came together as flat mates, migratory trajectories were modified. For Mohamed, who came to France in 2000 and had relatively few connections to Egyptians in Paris, involvement on the $25^{\text {th }}$ of January in the first gathering ${ }^{26}$ at Chatelet, was a moment of reconnection with his fellow citizens. ${ }^{27}$ While Tahrir was becoming a new forum for citizenship, political debates abroad grew on social media. In France, numerous associations were created in the wake of the revolution (the Committee for Solidarity with the Struggle of the Egyptian People, the Association of $25^{\text {th }}$ of January Youth, the Tahrir Square Movement, etc). The United States experienced a similar phenomenon: the Egyptian American Rule of Law Association (EARLA) invested itself in the promotion of the rule of law in Egypt; the American-Egyptian Strategic Alliance (AESA) aimed to influence political relations between the United States and Egypt in order to encourage security, stability and mutual prosperity in both countries and promote democratic values; a group of entrepreneurs launched NEGMA (Networking, Entrepreneurship, Growth, Mobilization, \& Action) at a conference in March 2012 at MIT (Massachusetts Institute of Technology), with the goal of connecting Egyptian businessmen with their expatriate counterparts (Soudy, 2013). It is worth noting that after an initial period of revolutionary enthusiasm, a number of these initiatives declined or disappeared.

In reality, only a minority of emigrants became seriously engaged in the revolutionary process, either by returning to Egypt or through activism in their host countries. The vast majority of emigrants were content to remain attentive and passionate spectators of the changes that were underway. It is still too soon to evaluate in a more precise way the involvement of Egyptians living abroad in sparking the revolution, but this appears to have been important, alongside the development of transnational political networks of Egyptian activists (Abdelrahman, 2011). During interviews I was able to carry out in Cairo in September 2011 among migrants who had returned from France, all indicated that they had participated in the Tahrir square protests and underscored that a large proportion of the protesters had had experiences abroad. 


\section{Revolution as an Accelerator of "Diasporization"28?}

the 'communities' abroad are very fragmented and little structured, with the exception of Copts (Pagès-El Karoui, 2012b; Severo and Zuolo, 2012). At the beginning of the revolutionary process, it was possible to think that the unfolding political changes might allow for a process of disasporization around common national references. Just before 2011, Mohamed El Baradei, former Director General of the International Atomic Energy Agency and Nobel Peace Prize winner, became an iconic figure for Egyptians abroad. He positioned himself as an alternative candidate to Mubarak in the future presidential elections, and a defender of the rights of emigrants: one of the leading measures of his National Assembly for Change was the right to vote for Egyptians abroad (see below). In 2010 he managed to mobilize many Egyptians during speeches in London, Washington, New York, and Boston.

After Mubarak's fall, the feeling that there was a connection between Egyptians abroad was predominant, from the United States to Qatar (Soudy, 2013). In France, the idea of 'forming a community' began to take root, whereas in interview conducted prior to 2011 the adage 'beware of the Egyptians abroad' was predominant. The same feeling of 'being one' through the erasure of differences that predominated during the 18 days on Tahrir square animated Egyptians in France. New and previously unseen encounters occurred between Egyptians from different worlds, such as the sans-papiers of the construction industry and highly educated students or executives. Common belonging was accentuated, even if social, political or gendered tensions stubbornly remained: a young woman from the Egyptian bourgeoisie was slapped twice by a vegetable seller whom she asked to drop 'death to Jews' from the slogans he was shouting. ${ }^{29}$ Belief in the myth of national unity existed, but with less conviction than on Tahrir square. There are several reasons for this. First, in Egypt, the fear of repression fed this collective imaginary; in France, such fear was much weaker, even if for the sans-papiers, protesting involved risk of arrest. In addition, the places where support for the revolutionary process was expressed were from the outset multiple (as in Egypt): the Fontaine des Innocents at Châtelet, following in the footsteps of the Tunisian movement which had already gathered there; Place du Trocadéro; the Egyptian Embassy (occupied for several days); Belleville, etc. Nowhere acquired the status of an iconic public space the way Tahrir square did, symbolically embodying the myth of unity.

These tensions were visible from the outset. For example there were competing protests that departed from different locations on the same day. Another example of tension occurred in a French-Egyptian association created to support the Egyptian revolution, where Egyptian activists rejected the involvement of French people who had lived in Egypt, considering this a kind of spoliation: 'It's our revolution. They're stealing it from us'. ${ }^{30}$ The dream of unity soon splintered, the revolutionary passion transforming itself into 'micromovements' ${ }^{31}$ and associations tearing themselves apart and dividing around two or three members, in personality conflicts (Ricci, 2013). These cleavages were deepened after president Morsi's destitution, as the tensions of Egyptian society were exported abroad. In Paris, incidents between those who were pro-Muslim Brotherhood and the rest increased, leading to the closure of the Egyptian cultural centre on boulevard Saint Michel. During a talk at the Institut du Monde Arabe (IMA) in October 2013, the Egyptian novelist Alaa Al-Aswany was so violently taken to 
task by Morsi partisans that security had to evacuate him from the conference room. While the desire to organize around a common belonging to the Egyptian nation that was temporarily experimented with during the early moments of enthusiasm has been lost, one new transnational political practice has, however, emerged: overseas voting.

\section{Voting Rights for Egyptians Abroad: A Postrevolutionary Innovation} particular (Lafleur, 2013; Collyer, 2014; Jaulin, 2014) is slowly being extended to Egypt (El Baradei, 2012; Brand, 2013). ${ }^{32}$ Yet, this innovation is one of the strongest symbols of the political transition and reflects a new imaginary concerning the equality of citizens, even if foreign voting is not necessarily an indication of democracy and president Sisi's election abruptly arrested the transition process. Nevertheless, this new right for expatriates attests to the enlargement of the boundaries of Egyptian citizenship and the assertiveness of Egyptian civil society, outside the country as much as inside it, who fought hard to obtain it.

\section{The Traditional Mistrust toward Egyptians Abroad}

The authorities have always been strongly suspicious of the loyalty of Egyptians abroad, even if their degrees of suspicion varied slightly after 2011 depending on whether the Islamists or the military was in power. In the constitutional declaration of 2011, promulgated by the Supreme Council of the Armed Forces, article 26 made the conditions of eligibility to the post of President stricter in terms of nationality: 'It is required for whoever is elected president of the republic to be an Egyptian who has never held another citizenship, born of two Egyptian parents who have never held another citizenship, enjoying his/her political and civil rights, not married to a nonEgyptian, and not falling under the age of 40 years. ${ }^{33}$ Hazem Salah Abu-Ismael, a Salafist candidate espousing violently anti-American rhetoric, ended up being excluded on the basis of this provision since his mother, who was by then dead, had held an American passport. The president of the committee in charge of revising the constitution justified the criteria by explaining that they were the ones used in military academies and should therefore apply to presidential candidates (Soliman, 2011).

This nationalistic (and military) vision of citizenship appears completely unsuited to the migratory reality of contemporary Egypt. It is doubly exclusive since it rules out of the national narrative both Egyptians of foreign origin, though they are entirely a part of it, as well as Egyptians living abroad, as though leaving the national territory inexorably leads to the erosion of national sentiment. This position is criticized by the political scientist Samer Soliman, who is in favour of the integration of Egyptians abroad, recalling in his argument the extent to which the development of China and Israel rests largely on the skills of expatriate and bi-national communities:

“The "conspiracy" against Egyptians abroad continues. Frankly speaking, sidelining Egyptians living abroad is not because of doubts about their patriotism but because of their potential. They are "suspected" of being competent and therefore pose a threat to the quasi-talented in government positions. They are also "suspected" of not succumbing to the authorities or being guided to vote in a certain way because their living standards are high and they are beyond the reach of the state security agency that continues its operations under other names' (Hafez and Khaly, 2012: 17). 
41 The new Egyptian Constitution adopted in December 2012 under Morsi's presidency eliminated the requirement that the candidate's parents never have held dual citizenship, however the president himself still could not hold dual citizenship or be married to a non-Egyptian. The economic contribution of emigrants to the development of their country is, on the other hand, strongly encouraged. Ultimately, the last Constitution, adopted in 2014 after Morsi's destitution, returned to the narrower view, allowing neither the candidate, his parents, nor his spouse to have held any other nationality.

\section{The Mobilization of Egyptians Abroad to Obtain the Right to Vote}

In October 2011, the administrative court confirmed the right to vote from abroad following two cases, of which one was brought by Egyptians living abroad, including the famous novelist Ahdaf Soueif, with support from the Hisham Mubarak Law Centre. This mobilization was orchestrated over social media and Twitter in particular (with the hashtags \#EgyAbroad and \#right2vote), in order to coordinate actions between Egyptians across various countries of residence. In October 2011, several protests were organized simultaneously in front of consulates and embassies in London, Washington, New York and Paris. ${ }^{34}$ This new right was acquired by means of intense mobilizations of Egyptian citizens, abroad and in Egypt alike, and it modified the relations between Egyptians and the institutions representing them abroad. They overcame their traditional suspicion of their embassy and consulate and registered themselves in large numbers at embassies, hoping to soon have the possibility of voting. ${ }^{35}$

\section{First Elections}

In the 2011-2012 legislative elections, Egyptians abroad were able to vote for the first time: 355,500 voters were registered in 163 different countries, of which 142,700 in Saudi Arabia. Unlike in Tunisia, they did not have separate representatives: their votes were counted in their place of last residence before leaving Egypt. For the presidential elections of 2012, the official Egyptian elections website ${ }^{36}$ indicates that of 586,803 registered voters, 311,875 cast ballots in the first round. These voter figures appear low in light of the millions of Egyptians who live abroad, but it must be recalled that low turnout is recurrent in overseas voting and that in fact, participation rates were higher abroad than inside Egypt: $53.6 \%$ compared to $47 \%$ in the first round, whereas the turnout rates converge around $52 \%$ for the second round (see tables 1 and 2 ). In addition, significant constraints limited the exercise of this right: first, not everyone is in possession of a national identity card, which was required to vote, and second, polling stations were limited to embassies and a few consulates, so many voters may not have made the trip when the distance was too great. Finally, voters had to present their residency permit, which deprived anyone in an irregular situation of the right to vote.

Table 1: 2012 Presidential Election (Round 1) $)^{37}$

\begin{tabular}{|l|l|l|l|l|l|}
\hline & Votes cast & Participation rate & Islamist & Ancien regime & Left \\
\hline Egyptians abroad & 311,875 & $53.6 \%$ & $62.7 \%$ & $21.3 \%$ & $15.9 \%$ \\
\hline
\end{tabular}




\begin{tabular}{|l|l|l|l|l|l|}
\hline Egypt total & $27,153,030$ & $47 \%$ & $43.3 \%$ & $35 \%$ & $21.5 \%$ \\
\hline
\end{tabular}

Source: High Elections Committee. URL: http://pres2012.elections.eg/index.php/round1-results

Table 2: 2012 Presidential Election (Round 2)

\begin{tabular}{|l|l|l|l|l|}
\hline & Votes cast & Participation rate & Morsi & Shafiq \\
\hline Egyptians abroad & 301,720 & $53.3 \%$ & $74.9 \%$ & $25.1 \%$ \\
\hline Egypt total & $25,577,511$ & $52 \%$ & $51.7 \%$ & $48.3 \%$ \\
\hline
\end{tabular}

Source: High Elections Committee. URL: http://pres2012.elections.eg/index.php/round2-results

Emigrants' enthusiasm for their new right resulted in long queues at embassies and consulates around the world, especially in the Gulf countries, which host the largest Egyptian communities. As protests are prohibited there, expatriates were not able, prior to that time, to publicly express their participation in the extraordinary changes their country was undergoing. This resulted in a truly novel situation, whereby Egyptians gave a public lesson in democracy to the Gulf countries that feared revolutionary 'contagion.' Among the forty Egyptians interviewed in Dubai, the vast majority participated in the elections, and only a few women declared that they had not voted and had not gotten interested in politics. However several people admitted to having abstained in round 2 of the presidential election, which was a runoff between the Muslim Brotherhood candidate Morsi, and the candidate of the former regime, Shafiq. ${ }^{38}$ The effect of these abstentions is visible in the decrease of the number of ballots cast (see Table 2).

What were the results of the vote? ${ }^{39}$ Did emigrants vote differently than their fellow citizens? The generally accepted hypothesis is that emigrants living in Western countries would have a tendency to be more liberal than those living in the Gulf, who would be more conservative (Fargues, 2011). The Tunisian case offers a counterexample: diaspora voters caused surprise, since the Islamists achieved equivalent scores among voters at home and abroad, even though the majority of overseas voters live in Western countries, in particular France..$^{40}$ In the Egyptian case the hypothesis seems to hold, since the Islamist vote is more significant among voters abroad than inside Egypt, and Egyptians in the Gulf and above all Saudi Arabia constitute the vast majority of overseas voters (cf. Map 1). ${ }^{41}$ But the situation varies from one country to another. The 'Islamist' vote was highest in Saudi Arabia, Bahrain, Qatar and Oman, whereas in the Emirates and Kuwait they had less success, potentially introducing a nuance in our understanding of the Gulf Cooperation Council (GCC), which is too often considered to be a homogeneous regional entity. Partisans of the old regime were more numerous in Greece, the Netherlands, Australia and the United States. In these countries, the presence of many Copts, who feared an Islamist victory, undoubtedly had an impact on the results.

In round 2, this tendency was confirmed: Egyptians abroad voted $74.9 \%$ for Morsi, a level of support achieved in very few governorates inside Egypt (except bastions of Muslim Brotherhood support, such as Fayoum), and the average was $51.7 \%$. In Saudi 
Arabia, the Muslim Brotherhood paid poor immigrants and transported them in buses to polling stations, according to two interviewees, a sign that common practices of fraud and clientelism persist. ${ }^{42}$

\section{Map 1: Egyptian overseas voting (Round 1 of the 2012 presidential election)}

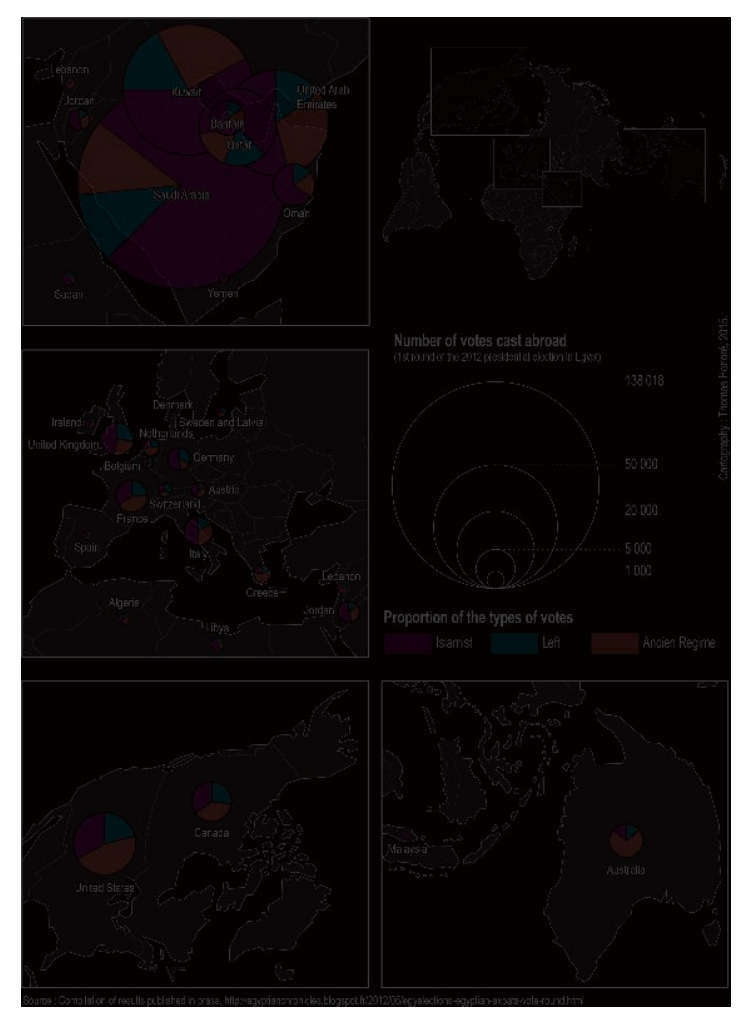

Source: Compilation of results published in the press. URL: http://egyptianchronicles. blogspot.fr/ 2012/05/egyelections-egyptian-expats-vote-round.html

\section{Emigrants' Increased Financial Contribution}

Savings transfers by emigrants reached 20 billion US dollars in 2014 and represent 7\% of Egypt's GDP, which receives the most remittances of any Arab country and is $6^{\text {th }}$ globally. Graph 1 shows a sharp increase in remittances after 2011. This source of income has become three times larger than revenues generated by the Suez Canal. We can observe irregular fluctuations in the 1970s and 1980s, stagnation in the 1990s, after the Gulf war caused many Egyptians to return home, and finally a sharp increase beginning in 2004. The rate of increase is slowed by two events: in 2009, the economic crisis of 2008, and in 2013, the return of 300,000 migrants from Saudi Arabia as a result of policies against illegal immigration.

While the increase had begun prior to 2011, the revolution clearly played a crucial role: the return of certain migrants (Libya, Saudi Arabia) who brought money back with them may have temporarily caused figures to bloat. While these returns then resulted in a decrease in remittances, this was compensated by other departures, while those remaining abroad maintained their levels of solidarity with relatives in Egypt, who have been hard-hit by the steadily worsening economic crisis since 2011. This income is especially welcome at a time when Egypt is in dire need of foreign currency. Should these increases be seen as a sign that the many initiatives to channel remittances 
succeeded? ${ }^{43}$ Several associations of Egyptians living abroad organized campaigns of this kind: the Egyptian American Cultural Association (EACA) launched a call for funds to support the families of martyrs (Soudy, 2013). In the Emirates, Banque Misr offered free money transfers for two months. The Central Bank of Egypt opened an account into which Egyptians abroad could deposit money to support the stock exchange and improve government exchange reserves (Abdelfattah, 2011). Policy on this point did not subsequently deviate under Morsi, as the video that he produced in English for Egyptians working abroad attests. ${ }^{44}$ Since then, Sisi has continued to move in the same direction: when he launched the new Suez Canal project, he called on all Egyptians and expatriates to contribute in solidarity with the project.

Figure 3: Evolution of Egyptian Remittances (1977-2014)

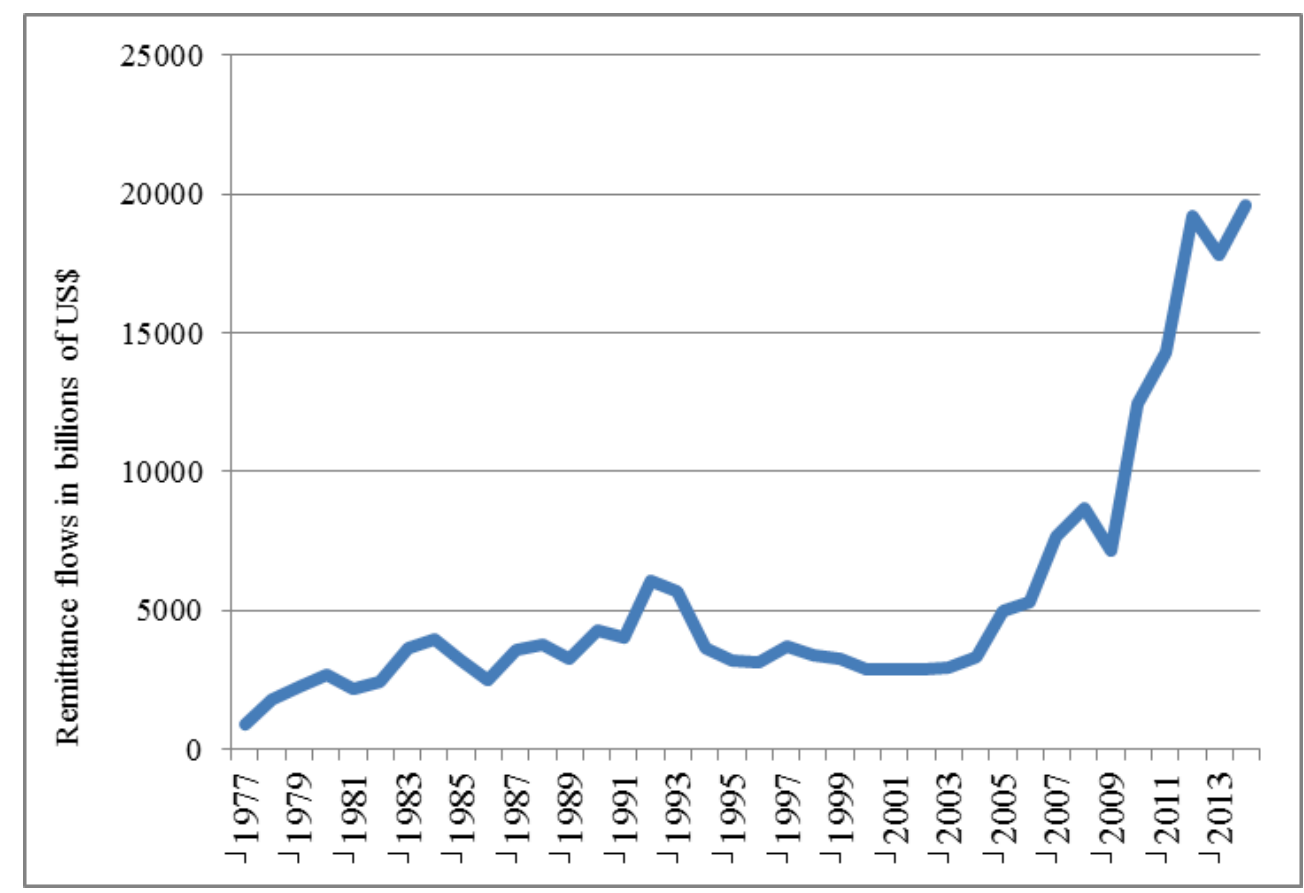

Source: World Bank. ${ }^{45}$

\section{Conclusion}

The balance sheet of the Arab spring with respect to Egyptian migrations is very complex to establish because we do not have reliable statistics for the Gulf countries, which are the main pole to which Egyptians are attracted, and because it varies according to different temporalities (for example, the exodus of Muslim Brothers in the fall of 2013, following Morsi's destitution), social groups (proportionally, the tendency to leave is more pronounced among copts) and the destination countries. The migratory field was not really destabilized by the revolution, even if new barriers arose for certain destinations, because of the geopolitical situation in Libya or the new governmental policies put in place in the Gulf to address the fear that contestation might spread. While 2011 undeniably opened a new cycle in the history of Egyptian migrations, the overall impact has been much weaker than in Syria, where waves of refugees have generated a humanitarian crisis, above all in the Middle East, and to a lesser degree in Europe. The return to authoritarianism and the significantly degraded 
economic situation will continue to feed into departures from Egypt, particularly since the country is increasingly locked in a cycle of violence, with a nearly insurrectional situation in Sinai and generalized instability, lending increased importance to security problems.

The post-2011 moment corresponds to a new period for Egyptian emigration, resulting in the intensification of transnational practices, an interrupted process of 'diasporization' and more generally by increased visibility of Egyptian communities abroad. The strength of transnational connections reactivated ties between migrants or their descendants and their country of origin. Emigration therefore does not signify the disappearance of all loyalty, to borrow Hirschman's (1970) term, toward the country of origin. Rather, the moral obligation to participate in one's country's development was a driver of many returns in the early moments after the revolution and appears to have resulted in an increase in remittances. Granting of the right to vote to emigrants attests to this enlarged national imaginary, and is a move in the direction of greater equality between citizens.

Contrary to many other countries of the region that have witnessed a collapse of the state, the crumbling of national identity in favour of more primary identifications, the Egyptian national narrative appears to have come out of the crisis strengthened. Indeed it is a burst of nationalism that allowed the return to authoritarianism. The national imaginary that was reinvigorated by the spirit of Tahrir but which today is carried forward by only a few activists, remains crosscut by profound contradictions. The nationalist option has been adopted by the vast majority of Egyptians, who consider it to be the only defense against the disasters that have prevailed across the Middle East.

\section{BIBLIOGRAPHY}

Abdelfattah Dina (2011) Impact of Arab Revolts on Migration, CARIM Analytic and Synthetic Notes 2011/68, [online]. URL: http://cadmus.eui.eu/bitstream/handle/1814/19874/ASN2011-68.pdf? sequence $=1$

Abdelrahman Maha (2011) The Transnational and the Local: Egyptian Activists and Transnational Protest Networks, British Journal of Middle Eastern Studies, 38 (3), pp. 407-424.

Anderson Benedict (2006) Imagined communities: reflections on the origin and spread of nationalism, Londres, New York, Verso (édition révisée), $240 \mathrm{p}$.

Beaugrand Claire (2013) Réforme du marché du travail en Arabie saoudite, Orient XXI, [en ligne] consulté le 10/06/2015. URL : http://orientxxi.info/magazine/reforme-du-marche-du-travail-enarabie-saoudite, 0304

Bianchi Robert (2012) Egypt's revolutionary Elections, The Singapore Middle East Papers, 2, 60 p. Brand Laurie (2014) Arab uprisings and the changing frontiers of transnational citizenship: voting from abroad in political transition, Political Geography, 41, pp. 54-63. 
Catusse Myriam (2012) Tunisie et Égypte aux urnes ! Révolution ou restauration de la sociologie électorale ?, Confluences Méditerranée, 82 (3), pp. 29-50.

Collyer Michael (2014) Inside out? Directly elected special representation of emigrants in national legislatures and the role of popular sovereignty, Political Geography, 41, pp. 64-73.

De Bel-Air Françoise (2014) Les migrations, un facteur de soulèvement des « printemps arabes »?, in M'hamed Ouadi, Delphine Pagès-El Karoui et Chantal Verdeil Éds., Les ondes de choc des révolutions arabes, Beyrouth, Presses de l'IFPO, pp. 249-267.

Dufoix Stéphane (2003) Les diasporas, Paris, Presses universitaires de France, 127 p.

El Baradei Laila, Wafa Dina and Ghoneim Nashwa (2012) Assessing the Voting Experience of Egyptians Abroad: Post the January 25 Revolution, Journal of US-China Public Administration, 9 (11), pp. 1223-1243.

Fargues Philippe (2011) International Migration and the Demographic Transition: A Two-Way Interaction, International Migration Review, 45 (3), pp. 588-614.

Fargues Philippe (2000) Générations arabes : l'alchimie du nombre, Paris, Fayard, 349 p.

Fargues Philippe and Fandrich Christine (2012) Migration after the Arab spring, MPC Research Report 2012/09, [online] last checked on 10/06/2015. URL: http:// www.migrationpolicycentre.eu/docs/MPC 2012 EN 09.pdf Ghonim Wael (2012) Révolution 2.0 : le pouvoir des gens, plus fort que les gens au pouvoir, Paris, Steinkis, $384 \mathrm{p}$.

Hafez Hend and Ghaly Ayman (2012) The Effect of the Arab Spring on Migration Flows in Egypt, MPC Research Report 2012/05, American University of Cairo, 21 p.

Hirschman Albert (1993) Exit, voice, and the fate of the German Democratic Republic. An Essay in Conceptual History, World Politics, 45 (2), pp. 173-202.

Hirschman Albert (1970) Exit, voice, and loyalty: responses to decline in firms, organizations and states, Cambridge Mass London, Harvard Press, 162 p.

IOM (2013) Policy in Brief-Two years after the crisis: returnees from Libya revisited, 10 p., [online] last checked on 01/06/2015. URL: http://publications.iom.int/bookstore/index.php?

main_page=product_info\&cPath=36\&products_id=923\&language $=\mathrm{fr}$

IOM (2011) Egypt after January 25: Survey of Youth Migration Intentions, Cairo, 35 p., [online] last checked on 01/06/2015. URL: http://www.egypt.iom.int/Doc/

IOM\%20\%282011\%29\%20Egypt\%20after\%20January\%2025\%20Survey\%20of\%20Youth\%20Migration\%20Intentions.pdf

Jaulin Thibaut (2014) Géographie du vote à distance : l'élection tunisienne de 2011 à l'étranger, L'Espace politique, 23, [en ligne] consulté le 11/06/2015. URL : https://espacepolitique.revues.org/ 3099

Lafleur Jean-Michel (2013) Transnational Politics and the State. The External Voting Rights of Diaspora, New York and London, Routledge, 190 p.

Levitt Peggy (1998) Social remittances: migration driven local-level forms of cultural diffusion, International Migration Review, 32, pp. 926-948.

Müller-Funk Lea (2014) Transnational Politics, women \& the Egyptian revolution: examples from Paris, Mashriq \& Mahjar, 2 (1), pp. 29-55.

Pagès-El Karoui Delphine (2015) L'Égypte après 2011, in Camille Schmoll, Hélène Thiollet et Catherine Wihtol de Wenden, Les Migrations en Méditerranée, Paris, éditions du CNRS, pp. 267-280. 
Pagès-El Karoui Delphine (2014) 2011, L'odyssée de l'espace public égyptien, in M'hamed Ouadi, Delphine Pagès-El Karoui et Chantal Verdeil Éds., Les ondes de choc des révolutions arabes, Beyrouth, Presses de l'IFPO, pp. 269-291.

Pagès-El Karoui Delphine (2012a) Géographie du changement social en Égypte, Echogéo, 21, [en ligne]. URL : http://echogeo.revues.org/13204

Pagès-El Karoui Delphine (2012b) Égyptiens d'outre-Nil : des diasporas égyptiennes, Tracés, 2 (23), pp. 113-130.

Pagès-El Karoui Delphine et Vignal Leïla (2011) Les racines de la « révolution du 25 janvier » en Égypte : une réflexion géographique, Echogéo, Sur le Vif, [en ligne]. URL : http:// echogeo.revues.org/12627

Pliez Olivier (2015) Libye, in Gildas Simon Éd., Dictionnaire des migrations internationales, Paris, Armand Colin, pp. 272-276.

Premazzi Vivianaa, Ambrosetti Elena, Cela Eralba and Fokkema Tineke (2013) The Arab Spring and the Return Intention of Egyptian Living in Italy, International Journal of Middle East Studies, 6 (2), pp. 109-131.

Ricci Simona (2013) Sur les traces de la révolution égyptienne à Paris : associations, militants, migrants, mémoire de Master 1 sous la direction de Nicolas Puig, Université Paris Diderot, 99 p.

Rougier Bernard et Bayoumi Hala (2015) Sociologie électorale de la séquence 2011-2013, in Bernard Rougier et Stéphane Lacroix Éds, L'Égypte en révolution, Paris, PUF, pp. 165-189.

Roussel Cyril (2012) Les migrations internationales de travail en Jordanie, Les Carnets de l'Ifpo. La recherche en train de se faire à l'Institut français du Proche-Orient, [en ligne]. URL : http:// ifpo.hypotheses.org/3491

Samer Soliman (2011) What is suspect about Egyptians abroad?, Ahramonline, [online]. URL: http://english.ahram.org.eg/NewsContentP/4/25786/Opinion/What-is-suspect-about-Egyptiansabroad.aspx

Senovilla Hernandez Daniel (2013) Mineurs isolés étrangers et sans protection en Europe. Rapport comparatiffinal, Rapport de recherche de l'enquête PUCAFREU, [en ligne], consulté le 07/07/2015, URL : http://www.mshs.univ-poitiers.fr/migrinter/PUCAFREU/

PUCAFREU\%20rapport\%20comparatif\%20FR.pdf

Severo Marta and Zuolo Eleonora (2012) Egyptian e-diaspora: Migrant websites without a network?, Social Science Information, 51, pp. 521-533.

Soudy Nada (2013) Expatriates versus immigrants: a comparative study of second-generations Egyptians in Qatar and the United States, MA Thesis, Georgetown University, 176 p.

Soueif Ahdaf (2012) Cairo: My City, Our Revolution, Londres, Bloomsbury Publishing PLC, 224 p. Thiollet Hélène (2013) Migrations, Exils et Printemps Arabes, Afrique du Nord-Moyen-Orient 2013-2014, Paris, La Documentation française, pp. 133-146.

Zhuo Xiaolin, Wellmann Barry and Yu Justine (2011) Egypt: The First Internet Revolt?, Peace Magazine, [online] last checked on 15/06/2012. URL: http://peacemagazine.org/archive/ v27n3p06.htm

Zohry Ayman (2013) Egypt's International Migration After the Revolution: Is there any change?, Confluences Méditerranée, 87 (4), pp. 47-54. 
Zohry Ayman (2009) The Impact of the Current Economic Crisis on Egyptian Migration and Egyptians Abroad, Working Papers Series n²009/1, The Egyptian Society for Migration Studies.

\section{NOTES}

1. This research was funded in the context of the SYSREMO (ANR) and ECOMIG (IRD) research programmes, as well as by URMIS.

2. For an overview of the impact of the Arab revolutions on the Egyptian migratory system (emigration and immigration), see Pagès-El Karoui, 2015.

3. Khaled Said is a young Alexandrian who was killed in June 2010 by the police for having published a video denouncing police corruption on the internet. His death generated a huge reaction in Egypt. A Facebook page in his honour played an important role in the organization of the January 2011 protests.

4. May Telmissany, speaking in the context of the 'Paroles de créateurs' speaker series at the INALCO, 16 June 2015.

5. Interview in Paris, June 2015.

6. Access to nationality is extremely restricted in the Gulf countries.

7. The Arabic title is a play on words that echoes that of a famous film from the 1970s, Ambrâturiyat Mîm, M's Empire.

8. Before 2011, Egyptian ministries claimed that there were 2 million Egyptians in Libya. According to Libyan estimates, there were 830,000 (Pliez, 2015).

9. The IOM puts the number of Egyptians who returned from Libya in an organized fashion at 173,873, which does not include those who returned by their own means (IOM, 2013).

10. Ahmed Nadia (2015) "In pursuit of bread: Why Egyptian workers are willing to risk their lives in Libya", Mada Masr, http://www.madamasr.com/sections/politics/pursuit-bread-whyegyptian-workers-are-willing-risk-their-lives-libya (accessed 4 May 2015).

11. Egypt-Libya: Returnees struggle to survive. URL: http://www.irinnews.org/report/94128/ egypt-libya-returnees-struggle-to-survive

12. Interview with an IOM official, Cairo, January 2015.

13. http://english.ahram.org.eg/NewsContent/1/64/134441/Egypt/Politics-/Egypts-borderguards-stop--from-passing-to-Libya-.aspx

14. Reuters, 1 December 2013, http://www.reuters.com/article/2013/12/01/us-libya-egyptidUSBRE9B00H220131201

15. Interview with a parent whose children attend the school, Cairo, January 2015.

16. Arabic document of the IDSC (Information and Decision Support Center), an Egyptian government think tank. It is important to note that the question posed embeds a significant bias, since it evokes permanent emigration, which for Egyptians is associated with emigration to the West. Since migration to Arab countries, particularly those in the Gulf, is generally thought of as temporary, that dimension is quite likely to have been underestimated.

17. In Italy, in 2010, Egypt was the $4^{\text {th }}$ ranking country in terms of the number of unaccompanied minors, after Afghanistan, Bangladesh, and Albania (Senovilla Hernandez, 2013).

$18 . \quad$ http://frontex.europa.eu/assets/Attachments_News/ unaccompanied_minors_public_5_dec.pdf

19. According to a study carried out by Girgis and Osman, cited by Zohry (2013), the revolution played an important catalytic role: $75 \%$ of Copts interviewed decided to emigrate after the revolution, a figure that falls to $42 \%$ for Muslims.

20. See the article of Hélène Thiollet in this volume.

21. Interview with Amin, an Egyptian software designer, Dubai, February 2015. 
22. http://www.arabnews.com/news/483296

23. During an interview, the following incident was recounted: a woman, whose husband lived in Dubai, was stopped by armed men while driving in her car with her children in Cairo. They demanded a ransom from her husband who succeeded in negotiating their release and then decided to bring them to Dubai to live with him.

24. There would, on the other hand, be a lot to say about the securitization of the treatment of immigrants to Egypt after 2011, however that is beyond the scope of this article.

25. See also the article of Célia Lamblin in this volume.

26. It is, on the other hand, much more complicated to publicly express support for the revolutionary process in Arab countries. Thus, Ayman, a 34 year-old engineer who has lived in Dubai since 2008, wished to organize a protest to display support after the $25^{\text {th }}$ of January. He was quickly dissuaded from doing so by the police, from whom he had asked for authorization (interview, Dubai, February 2014).

27. Interview, Paris, June 2015.

28. Since the 1990s, the concept of diaspora has been very frequently used to evoke any form of large scale dispersion of a group that manages to maintain ties with its territory of origin and a sense of common identity going beyond this territory. Many efforts to define diaspora have been made, based on various criteria (dispersion, strong link to the country of origin and desire to return, consciousness of group unity and collective memory, existence of institutions that connect the different poles of the diaspora to one another and the territory of origin, etc). Stéphane Dufoix's work (2003) underscores that it is an illusion to think that diasporas have essence, community and continuity, and invites an analysis of these social constructions in terms of processes of identification, differentiation and historicity. 'Diasporization' refers to these processes.

29. Interview, Paris, June 2015.

30. Related in an interview, Paris, June 2015.

31. Interview, Paris, June 2015. See also (Ricci, 2013).

32. However, recent articles on post-2011 Egyptian elections (Bianchi, 2012; Catusse, 2012; Rougier and Bayoumi, 2015) never mention this postrevolutionary innovation, which came into effect in October 2011. In fact, law 73 of 1953, amended by law 173 of 2005, authorized voting in consulates, but nothing had been done to ensure its application. This right was confirmed by the 2012 Constitution.

33. http://mjp.univ-perp.fr/constit/eg2011a.htm

34. El Gundy, 'In an historic ruling, Egyptian court confirms voting rights for millions of expats,' 25 October 2011, Al-Ahram on-line. http://english.ahram.org.eg/NewsContent/1/64/25116/ Egypt/Politics-/In-a-historic-ruling,-Egyptian-court-confirms-voti.aspx

35. Nevertheless, suspicion toward consular officials persisted after 2011, as was clear in interviews with Egyptians in France and the Emirates.

36. Official site of the High Elections Committee (in Arabic): https://www.elections.eg/

37. For greater legibility, the results of M. Morsi, AM. Aboul Fotouh, MS. al Awa, A. al Ashal have been consolidated under the heading 'Islamist'; those of A. Moussa, A. Shafik, H. Khairallah, M. Galal, MF Eissa under the heading 'Ancien regime'; and H. Sabahi, Kh. Ali, A. al Hariri, H. alBastawisi under the heading 'Left'.

38. A general in the air force, he was Mubarak's prime minister in February 2011.

39. On the website of the High Elections Committee, results are displayed according to district (markaz) for both rounds, which provides quite a lot of detail. Curiously, however, the vote of Egyptians abroad are amalgamated. The cartography of the diaspora's vote uses data based on results published in the press. URL: http://egyptianchronicles.blogspot.fr/2012/05/egyelectionsegyptian-expats-vote-round.html

40. See the article by Thibaud Jaulin in this volume. 
41. Egyptians in Saudi Arabia represent $45 \%$ of those registered to vote, and the GCC as a whole, $83 \%$.

42. Interviews in Cairo and Dubai, 2015.

43. Expatriates were also encouraged to return to the country to support the heavily affected tourism sector.

44. https://www.youtube.com/watch?v=NPj0K6douaU

45. Annual Remittances Data, available on the website of the World Bank.

\section{ABSTRACTS}

This paper examines the impacts of the Arab revolutions on Egyptian emigration, attending to the diverse temporalities of political life in the country and the region between 2011 and 2015 . New flows, new reasons for migration (instability, insecurity), and new transnational practices (overseas voting) have arisen. During the postrevolutionary period, transnational practices gained momentum, a diaspora began to emerge (though this process was soon cut short), and Egyptian communities abroad became more visible. Transnational connections between Egyptians as well as migrants' or their descendants' links with Egypt were strengthened. Emigration doesn't mean an exit which makes all sense of loyalty disappear: the moral obligation to participate in their country's development fuelled the return of many migrants in the early days of the revolution. Nevertheless, the field of Egyptian migration has not been completely reconfigured by the Arab revolutions.

Cet article examine l'impact des révolutions arabes sur l'émigration égyptienne, selon les temporalités qui ont scandé la vie politique entre 2011 et 2015. Pendant cette période, sont apparus de nouveaux flux, motifs d'émigration (instabilité, insécurité) et pratiques transnationales (vote à distance). Le moment post-révolutionnaire s'est traduit par l'intensification des pratiques transnationales, par l'émergence ponctuelle d'un processus de diasporisation et, plus globalement, par une visibilité accrue des communautés égyptiennes à l'étranger. La force des connexions transnationales a réactivé les liens qu'entretenaient les migrants ou leurs descendants avec l'Égypte. L'émigration n'équivaut pas à une défection qui ferait disparaître toute loyauté: l'obligation morale de participer au développement de son pays a été le moteur de nombreux retours dans les premiers temps. Pour autant, le champ migratoire égyptien n'a pas été entièrement bouleversé par les révolutions arabes.

Este artículo examina el impacto de las revoluciones árabes en la emigración egipcia, según las temporalidades que han determinado el ritmo de la vida política entre 2011 y 2015. Durante este periodo han aparecido nuevos flujos, motivos de emigración (inestabilidad, inseguridad) y prácticas transnacionales (voto a distancia). El momento post-revolucionario se ha traducido en una intensificación de las prácticas transnacionales, a partir de la emergencia puntual de un proceso de diáspora y, de forma más global, a partir de una mayor visibilidad de las comunidades egipcias en el extranjero. La fuerza de las conexiones transnacionales ha reactivado los vínculos que mantenían los migrantes o sus descendientes con Egipto. La emigración no equivale a una deserción susceptible de hacer desaparecer toda lealtad: la obligación moral de participar al desarrollo del país fue el motor de numerosos retornos durante una primera etapa. A pesar de 
ello, el campo migratorio egipcio no ha sido completamente transformado por las revoluciones árabes.

INDEX

Palabras claves: migración, revolución, Egipto, transnacional, diáspora

Keywords: migration, revolution, Egypt, transnational, diáspora

Mots-clés: migration, révolution, transnational, diaspora

Geographical index: Égypte

AUTHOR

DELPHINE PAGÈS-EL KAROUI

Lecturer at the INALCO, on secondment to the CNRS in the URMIS research unit (2014-2015).

INALCO, 65 rue des Grands Moulins, 75013 PARIS; dpages@inalco.fr 